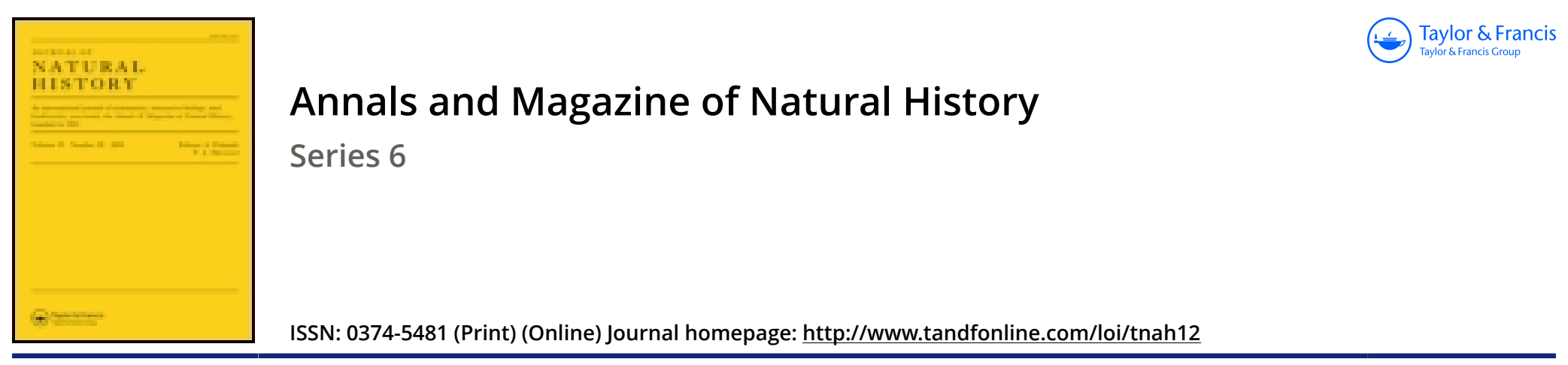

\title{
L.-Two new Buprestidæ from Damma Island
}

\section{Charles O. Waterhouse}

To cite this article: Charles O. Waterhouse (1892) L.-Two new Buprestidæ from Damma Island, Annals and Magazine of Natural History, 10:59, 410-412, DOI: 10.1080/00222939208677437

To link to this article: http://dx.doi.org/10.1080/00222939208677437

\section{Published online: 02 Oct 2009.}

Submit your article to this journal

Џ Article views: 3 
genus Uroderma, and may be readily distinguished from the other two, $A$. planirostris and bilobatus, by its nose-leaf being bound down to the muzzle in front as well as by the detailed differences in external structure and dentition above described.

XLIX.-Note on Mexican Examples of Chilonycteris Davyi, Aray. By OldField Thomas.

Wiru the specimens of Geomys Bulleri described in the August number of the 'Annals' (suprò, p. 196) Dr. A. C. Buller has sent to the Museum five specimens of a Chilonycteris apparently referable to the Trinidad and Brazilian C. Davyi, Gray, but distinguished at the same time by their brilliant fulvous-chestnut colour and by their slightly smaller size. The species was incidentally recorded from Mexico by Prof. Peters in his paper on the group*, but no Mexican, or even Central American, specimens have previously come to England. On direct comparison now with the type from Trinidad and with Dominican and Venezuelan specimens I have come to the conclusion that the Mexican ones ought to be subspecifically separated on the colour and size characters above mentioned, and would propose for them the name of Ch. Davyi fulvus, subsp. $\mathrm{n}$. The brilliant fulvous colour is not unlike that of male specimens of Natalus stramineus, but does not seem to be, as in that animal, a sexual character, for Dominican examples of both sexes are of precisely the same greyish or brownish hue.

The forearm of the type measures 43 millim. in length, and in the four other specimens $42 \cdot 5,43 \cdot 5,44$, and 45 .

Dr. Buller obtained the specimens at Las Peñas, west coast of Jalisco, on the 20th November, 1891.

\section{L.-Two new Buprestidæ from Damma Island. By Charles O. Wa'terhouse.}

AmoNG the insects collected by Mr. J. J. Walker during the cruise of H.M.S. 'Penguin' is a small collection made at Damma Island, north-east of Timor. The species are mostly small, and will require much time to determine; but two fine

tinguishable with that animal, however, from $A$. Hartii by the characters of its nose-leaf. It is also somewhat larger, having, as Dr. Matschie, of the Berlin Museum, kindly informs me, the second skull-measurement above given 7.5 millim., and the third 9.9 or 10 ; its forearm measures 47 millim.

* MB. Ak. Berl. 1872, p. 361. 
Buprestidæ are certainly new, and of these I subjoin descriptions. In order to make the position of one of these clear I must first make some remarks on the following genera :-

\section{Chrysodema, Pseudochrysodema, and Paracupta.}

The species of Chrysodema have metallic tarsi and have in nearly all cases a smooth, slightly raised, median line to the thorax.

The species of Paracupta have yellow tarsi and an impressed median line to the thorax.

Pseudochrysodema, Saund. (Cist. Ent. i. p. 223), occupies an intermediate place between these, having yellow tarsi, but having a raised median line to the thorax; it has, moreover, a distinct projecting angle to the elytra just below the shoulder.

The interesting species which I describe below has yellow tarsi and a raised median line to the thorax, and has also a subhumeral angulation. In these respects it comes nearest to Pseudochrysodema; it has, however, quite a different appearance from the two described species, having evenly convex elytra, the thorax with scarcely any trace of lateral impression, but at the base of the thorax are two small, elongate, sharply cut fovex, which are not present in Pseudochrysodema nor in any species of Chrysodema known to me. I think, nevertheless, that it would be premature to propose a new genus for the present species.

\section{Psєudochrysodema (?) Walleeri, sp. n.}

Aureo-viride, nitidum ; thorace subtiliter punctulato, linea mediana vix elevata lævi, lateribus leviter impressis crebrius punctatis, basi utrinque fovea parva insculpta ; elytris nigro-cyaneis, convexis, punctatis, haud costatis, ad apicem bene acuminatis acute serratis ; tarsis flavis, unguibus æneis ; antennis articulis $3^{0}-11^{\mathrm{m}}$ nigris.

Long. 15 lin.

The thorax is gently convex, only slightly narrowed in front, finely and not very closely punctured on the disk, more closely and rather more strongly punctured at the sides, which are very lightly impressed at the middle; there is a smooth slightly raised median line, with the usual impressed punctured line on each side of it ; the posterior angles are nearly right angles, and do not project laterally; on each side of the base, at a short distance from the posterior angles, there is a short, oblique, narrow, deeply impressed fovea. The elytra are convex, most so at a short distance from the base, with a 
distinct projecting angle just below the shoulder, and with the margins at the apical portion strongly and acutely serrate, distinctly punctured, except near the suture at a short distance from the base, the usual costre indicated by lines of punctures. The underside of the insect resembles that of Chrysodema radianum, but is more golden, and all the median area is more flattened; this is particularly noticeable at the inner part of the posterior coxæ, which forms a more distinct angle with the rest of the coxa. The tarsi are pale rusty yellow. The apical segment of the abdomen has a very small acute notch.

\section{Cyphogastra abdominalis, sp. $\mathrm{n}$.}

Viridis, nitida; thoracis disco utrinque cyaneo suffuso; elytris sat fortiter punctatis, ad apicem lævioribus, fere nigris, ad latera postice aureo-viridi suffusis, margine ipso cupreo tincto ; corpore subtus aureo-viridi, lateribus abdomineque læte cupreis, hoc vittis quatuor sordide albis ornato.

Long. 13-16 lin.

Very like $C$. nigripennis, Th., but rather broader and more strongly punctured, with the apex of the elytra formed as in C. calepyga, Th. The elytra nearly black, but have a distinct dark blue shade in some lights, the margins more or less green or golden green. The body beneath is green (with the usual yellow powder here and there), with the sides, and especially the abdomen, reddish coppery.

Two examples show a slight pale bluish-green shade at the suture of the elytra near the apex. Some examples have the metasternum coppery. One specimen has a little green shade on the abdomen.

\section{MISCELLANEOUS.}

Doubly-armoured Herrings. By A. SMITH Woodward.

IN his studies of the herrings of New South Wales, Mr. J. Douglas Ogilby * has lately made an interesting observation, of which he does not appear to appreciate the significance. In describing a new species, Clupea sprattellides, from the rivers flowing into Port Jackson and Botany Bay, he remarks that it differs from all the

* Records of the Australian Museum, vol. ii. p. 24 (August 1892). 